\title{
Genetic variations of nucleoprotein gene of influenza A viruses isolated from swine in Thailand
}

\author{
Nattakarn Thippamom', Donreuthai Sreta', Pravina Kitikoon', Roongroje Thanawongnuwech', Yong Poovorawan², \\ Apiradee Theamboonlers², Kamol Suwannakarn², Sujira Parchariyanon ${ }^{3}$, Sudarat Damrongwatanapokin ${ }^{3}$, \\ Alongkorn Amonsin ${ }^{1 *}$
}

\begin{abstract}
Background: Influenza A virus causes severe disease in both humans and animals and thus, has a considerably impact on economy and public health. In this study, the genetic variations of the nucleoprotein (NP) gene of influenza viruses recovered from swine in Thailand were determined.

Results: Twelve influenza A virus specimens were isolated from Thai swine. All samples were subjected to nucleotide sequencing of the complete NP gene. Phylogenetic analysis was conducted by comparing the NP gene of swine influenza viruses with that of seasonal and pandemic human viruses and highly pathogenic avian viruses from Thailand $(n=77)$. Phylogenetic analysis showed that the NP gene from different host species clustered in distinct host specific lineages. The NP gene of swine influenza viruses clustered in either Eurasian swine or Classical swine lineages. Genetic analysis of the NP gene suggested that swine influenza viruses circulating in Thailand display 4 amino acids unique to Eurasian and Classical swine lineages. In addition, the result showed 1 and 5 amino acids unique to avian and human lineages, respectively. Furthermore, nucleotide substitution rates showed that the NP gene is highly conserved especially in avian influenza viruses.

Conclusion: The NP gene sequence of influenza A in Thailand is highly conserved within host-specific lineages and shows amino acids potentially unique to distinct NP lineages. This information can be used to investigate potential interspecies transmission of influenza A viruses. In addition, the genetic variations of the NP gene will be useful for monitoring the viruses and preparing effective prevention and control strategies for potentially pandemic influenza outbreaks.
\end{abstract}

\section{Background}

Influenza A virus poses a serious threat to public health worldwide, particularly the virus circulating in humans and animal species such as birds, pigs and horses. Influenza A subtypes H1-3 and N1-2 have been circulating in the human population, while Influenza A subtypes $\mathrm{H} 1$ and 3 and N1-2 have been reported in swine. On the other hand, all H1-16 and N1-9 can be found in avian species $[1,2]$. The virus genome contains 8 segments of single-stranded RNA that encode 10-11

\footnotetext{
* Correspondence: alongkorn.a@chula.ac.th

'Emerging and Re-emerging Infectious Diseases in Animals, Research Unit, Faculty of Veterinary Science, Chulalongkorn University, Bangkok, 10330, Thailand

Full list of author information is available at the end of the article
}

proteins. Among those genes, the NP gene plays a major role with regard to host range or host species barriers for influenza A virus [3-5]. Genetic analysis of the NP gene has facilitated identification of particular amino acids correlated with host specificity [6]. At least two large classes of NP gene, human and non-human, had been classified by phylogenetic analysis $[3,7,8]$. NP protein functions include encapsidation of the virus genome for RNA transcription, replication and packaging [9], interaction with polypeptides in nuclear localization signals [10], direct interaction with viral polymerase for unprimed viral replication [11] and cytotoxic T lymphocyte activation $[12,13]$.

Recently, an influenza virus originating from swine (S-OIV 2009) has emerged in humans and subsequently

\section{Biomed Central}


spread worldwide. The 8 gene segments of the pandemic (H1N1) 2009 virus originated from human lineage (PB1), avian lineage (PB2, PA), Eurasian swine lineage (NA, M) and classical swine lineage (HA, NP, NS) $[14,15]$. This serves as an example that certain influenza A strains can harbor an NP gene that might not be host specific, such as the S-OIV in humans. The $\mathrm{NP}$ gene of S-OIV has been suggested to originate from the classical swine influenza virus.

As of April 2010, approximately 166 nucleotide sequences of the NP gene of influenza A viruses from Thailand have been reported to the public database (NCBI Influenza Virus Database). Among these 166 sequences, 97 were from avian $(\mathrm{H} 5 \mathrm{~N} 1=96$ and $\mathrm{H} 3 \mathrm{~N} 2=1), 55$ from human $(\mathrm{H} 1 \mathrm{~N} 1=24, \mathrm{H} 3 \mathrm{~N} 2=22$, and $\mathrm{H} 5 \mathrm{~N} 1=9)$ and 14 from swine $(\mathrm{H} 1 \mathrm{~N} 1=1, \mathrm{H} 1 \mathrm{~N} 2=$ 1 , and $\mathrm{H} 3 \mathrm{~N} 2=6$ ) viruses. In addition, most of the 166 sequences originated from virus isolated between 2000 and 2009, except for one virus that had been isolated in 1976. Due to the limited information on the NP gene of influenza viruses recovered from various species especially swine in Thailand, the objective of this study was to determine the genetic variation of the NP gene of influenza viruses isolated from swine in Thailand. In addition, the NP gene sequences of seasonal and pandemic 2009 human viruses as well as highly pathogenic avian influenza were retrieved from the database and included in the analysis.

\section{Results}

\section{Complete NP gene of Thai swine influenza viruses}

During 2005-2009, 12 swine influenza viruses were isolated from areas of intensive swine farming in central and eastern regions of Thailand. The 12 swine influenza isolates were identified as subtypes H1N1 $(n=6), \mathrm{H} 1 \mathrm{~N} 2$ $(\mathrm{n}=1)$ and H3N2 $(\mathrm{n}=5)$ based on RT-PCR using subtype specific primers. To study the genetic variation of the viruses, nucleotide sequencing was performed on the complete NP gene of 12 swine influenza isolates. The resulting sequences were submitted to the GenBank database under accession numbers HM142746HM142757. Virus characteristics and GenBank accession numbers of NP gene sequences are shown in table 1. In addition, the NP gene sequences of Thai avian $(\mathrm{n}=25)$, human $(\mathrm{n}=25)$, and swine $(\mathrm{n}=14)$ influenza viruses retrieved from the public database (GenBank) were included in the analysis (Table 1).

\section{Phylogenetic analysis}

Phylogenetic analysis of 76 different NP nucleotide sequences of human $(n=25)$, avian $(n=25)$, swine $(\mathrm{n}=14)$ Thai isolates and one reference NP nucleotide sequence of equine $(n=1)$ virus showed that the viruses clustered in distinct lineages represented by the avian, human, classical swine and Eurasian swine lineages (Fig 1). The avian NP lineage contains all avian influenza virus subtypes H5N1 $(\mathrm{n}=24)$ and H3N2 $(\mathrm{n}=1)$. In addition, all human H5N1 viruses $(\mathrm{n}=6)$ also clustered in this avian NP lineage. A human NP lineage comprises two groups of seasonal human influenza subtypes H3N2 $(n=8)$ and H1N1 $(n=3)$. In contrast, the pandemic 2009 influenza subtype H1N1 $(\mathrm{n}=8)$ clustered with the classical swine NP linage. The swine influenza viruses can be divided into 2 distinct lineages, Eurasian swine lineage and classical swine lineage. Based on topology of the phylogenetic tree, the Eurasian swine lineage is closely related to the avian lineage and had been previously designated "avian-like swine lineage" $[3,16]$. Eighteen swine virus subtypes H1N1, H1N2 and H3N2 from 2000-2009 clustered in this Eurasian swine lineage. On the other hand, 8 swine virus subtypes $\mathrm{H} 3 \mathrm{~N} 2$ and $\mathrm{H} 1 \mathrm{~N} 1$ were grouped with the classical swine lineage. It is noteworthy that 12 swine viruses characterized in this study clustered in both the Eurasian $(\mathrm{H} 1 \mathrm{~N} 1=5, \mathrm{H} 1 \mathrm{~N} 2=1$, and $\mathrm{H} 3 \mathrm{~N} 2=2)$ and classical swine lineage $(\mathrm{H} 3 \mathrm{~N} 2=4)$ (Table 1 and Fig 1$)$. It should be noted that Thailand has imported swine for breeding from both Europe and North America. In general, phylogenetic analysis of NP gene sequences of influenza A viruses indicated that the NP gene is highly conserved and largely grouped within the host range of the respective virus.

\section{Genetic analyses}

Pair-wise NP gene sequence comparisons of swine influenza viruses with 5 representative influenza viruses of equine (PR/56), avian (CUK2), human (CU32), Eurasian swine (9469/04) and classical swine lineages (K5/04) are shown in table 2 . The Thai swine influenza viruses were found similar to 2 distinct lineages, the Eurasian and classical swine lineages. Eight swine influenza viruses displayed a high percentage of nucleotide identity (93.5$99.7 \%$ ) to the European swine lineage $(9469 / 04)$. On the other hand, 4 swine influenza viruses were similar to the classical swine lineage (K5/04) with 90.5-93.6\% nucleotide identity. The deduced amino acids of the NP genes of 77 influenza viruses were compared to evaluate the host-specific nature of the NP gene. Few amino acid differences between lineages were detected indicating the highly conserved nature of the NP gene especially, in the avian lineage (table 3). Various reports have documented that particular amino acids are unique to distinct NP lineages [3]. In this study, one amino acid at position 105 was found correlated with the avian specific lineage $(105 \mathrm{~V})$. In the human lineage, 5 amino acids at positions 16 (16D), 283 (283P), 293 (293K), 372 (372D), and $422(422 \mathrm{~K})$ were highly conserved as human-specific amino acids. Moreover, some amino 
Table 1 Influenza A isolates from human, swine and avian hosts used in this study

\begin{tabular}{lcccc}
\hline Virus & Subtype & Year & GenBank \# & Lineage \\
\hline Equine virus & & & \\
A/Equine/Prague/1/56 & H7N7 & 1956 & M63648
\end{tabular}

Avian virus

A/Chicken//Thailand/CU-K2/04

A/Duck/Thailand/71.1/04

A/Goose/Thailand/79/04

A/Chicken/Thailand/CU-23/04

A/Chicken/Thailand/73/04

A/Chicken/Thailand/CK-160/05

A/Quail/Thailand/QA-161/05

A/Chicken/Thailand/CK-162/05

A/Chicken/Thailand/NIAH108192/05

A/Chicken/Thailand/PC-170/06

A/Chicken/Thailand/PC-168/06

A/Chicken/Thailand/NP-172/06

A/Watercock/Thailand/CU-334/06

A/Quail/Thailand/CU-330/06

A/Duck/Thailand/KU-56/07

A/Duck/Thailand/CU-328/07

A/Duck/Thailand/CU-329/07

A/Chicken/Thailand/NS-341/08

A/Chicken/Thailand/NS-342/08

A/Chicken/Thailand/NS-339/08

A/Chicken/Thailand/PC-340/08

A/Chicken/Thailand/ST-351/08

A/Chicken/Thailand/CU-354/08

A/Chicken/Thailand/CU-355/08

A/Duck/Thailand/AY-354/08

\section{Human virus}

A/Thailand/5-KK-494/04

A/Thailand/2-SP-33/04

A/Thailand/1-KAN-1/04

A/Thailand/676/05

A/Thailand/NK165/05

A/Thailand/CU23/06

A/Thailand/CU32/06

A/Thailand/CU46/06

A/Thailand/CU51/06

A/Thailand/NBL1/06

A/Thailand/CU280/07

A/Thailand/CU282/07

A/Thailand/CU356/08

A/Thailand/CU370/08

A/Thailand/CU1103/08

A/Thailand/CU-B4/09

A/Thailand/CU-B42/09

A/Thailand/102/09

A/Thailand/104/09

A/Thailand/CU-B5/09

$\begin{array}{ll}H 5 N 1 & 2004 \\ H 5 N 1 & 2004 \\ H 5 N 1 & 2004 \\ H 5 N 1 & 2004 \\ H 5 N 1 & 2004 \\ H 5 N 1 & 2005 \\ H 5 N 1 & 2005 \\ H 5 N 1 & 2005 \\ H 5 N 1 & 2005 \\ H 5 N 1 & 2006 \\ H 5 N 1 & 2006 \\ H 5 N 1 & 2006 \\ H 5 N 1 & 2006 \\ H 5 N 1 & 2006 \\ H 5 N 1 & 2007 \\ H 5 N 1 & 2007 \\ H 5 N 1 & 2007 \\ H 5 N 1 & 2008 \\ H 5 N 1 & 2008 \\ H 5 N 1 & 2008 \\ H 5 N 1 & 2008 \\ H 5 N 1 & 2008 \\ H 5 N 1 & 2008 \\ H 5 N 1 & 2008 \\ H 3 N 2 & 2008\end{array}$

AY590579
AY651496
AY651497
AY770996
DQ076203
DQ334761
DQ334769
DQ334777
AB450586
DQ999891
DQ999883
DQ999877
EU616887
EU616855
EU221252
EU616839
EU616847
EU850417
EU850425
EU620657
EU620665
FJ868015
CY047458
CY047462
FJ802402

Avian

Avian

Avian

Avian

Avian

Avian

Avian

Avian

Avian

Avian

Avian

Avian

Avian

Avian

Avian

Avian

Avian

Avian

Avian

Avian

Avian

Avian

Avian

Avian

Avian

H5N1 2004

H5N1 2004

H5N1 2004

H5N1 2005

H5N1 2005

Seasonal H3N2

2006

Seasonal H1N1 2006

Seasonal H3N2 2006

Seasonal H1N1 2006

H5N1

Seasonal H3N2

2006

Seasonal H3N2

Seasonal $\mathrm{H} 3 \mathrm{~N} 2$

Seasonal H3N2

Seasonal H3N2

Seasonal H3N2

Seasonal H1N1

Pandemic H1N1

Pandemic H1N1

2007

2007

2008

2008

2008

2009

2009

AY627889

Avian

AY627895

Avian

AY626145

Avian

DQ360840

Avian

DQ372594

Avian

FJ912940

Human

FJ912910

FJ912922

FJ912928

GQ466183

FJ912964

FJ912970

FJ912977

FJ912985

FJ913012

GQ902794

GQ902802

GQ166232

GQ169385

Human

Human

Human

Avian

Human

Human

Human

Human

Human

Human

Human

Classical swine

Pandemic H1N1
2009

2009
GQ866952 
Table 1: Influenza A isolates from human, swine and avian hosts used in this study (Continued)

\begin{tabular}{|c|c|c|c|c|}
\hline A/Thailand/CU-H9/09 & Pandemic H1N1 & 2009 & GQ866960 & Classical swine \\
\hline A/Thailand/CU-H106/09 & Pandemic H1N1 & 2009 & GQ866932 & Classical swine \\
\hline A/Thailand/CU-H276/09 & Pandemic H1N1 & 2009 & GQ866933 & Classical swine \\
\hline A/Thailand/CU-H340/09 & Pandemic H1N1 & 2009 & GQ866934 & Classical swine \\
\hline A/Thailand/CU-B938/09 & Pandemic H1N1 & 2009 & GQ866935 & Classical swine \\
\hline
\end{tabular}

Swine influenza virus

A/Swine/Thailand/KU5.1/04

A/Swine/Thailand/NIAH1481/00

A/Swine/Thailand/NIAH550/03

A/Swine/Thailand/NIAH9469/04

A/Swine/Thailand/NIAH977/04

A/Swine/Thailand/NIAH589/05

A/Swine/Thailand/NIAH587/05

A/Swine/Thailand/NIAH13021/05

A/Swine/Thailand/NIAH-NW/03

A/Swine/Thailand/NIAH464/04

A/Swine/Thailand/NIAH59/04

A/Swine/Thailand/NIAH874/05

A/Swine/Thailand/NIAH101942/08
A/Swine/Thailand/NIAH586-1/05

\section{H3N2 \\ $\mathrm{H} 1 \mathrm{~N} 1$ \\ H1N1 \\ H1N1 \\ H1N1 \\ H1N1}

$\mathrm{H} 1 \mathrm{~N} 1$

$\mathrm{H} 1 \mathrm{~N} 2$

$\mathrm{H} 3 \mathrm{~N} 2$

$\mathrm{H} 3 \mathrm{~N} 2$

$\mathrm{H} 3 \mathrm{~N} 2$

$\mathrm{H} 3 \mathrm{~N} 2$

$\mathrm{H} 3 \mathrm{~N} 2$

H1N1

Swine virus characterized in this study

A/Swine/Thailand/CB-HF6/05

A/Swine/Thailand/06CB2/06

A/Swine/Thailand/CU-CB1/06

A/Swine/Thailand/CS-K1/08

A/Swine/Thailand/CU-CBP18/09

A/Swine/Thailand/CU-CHL2/09

A/Swine/Thailand/CB-NIAH586/05

A/Swine/Thailand/NP-NIAH586-2/05

A/Swine/Thailand/CS-NIAH586-3/05

A/Swine/Thailand/NIAH586-4/05

A/Swine/Thailand/CB-S1/05

A/Swine/Thailand/CU-CB8.4/07
H1N1

H1N1

H1N1

H1N1

H1N1

H1N2

$\mathrm{H} 3 \mathrm{~N} 2$

$\mathrm{H} 3 \mathrm{~N} 2$

$\mathrm{H} 3 \mathrm{~N} 2$

$\mathrm{H} 3 \mathrm{~N} 2$

$\mathrm{H} 3 \mathrm{~N} 2$

H3N2

\section{4 \\ 2000 \\ 2003 \\ 2004 \\ 2004 \\ 2005$$
2005
$$$$
2005
$$$$
2003
$$

$$
2003
$$$$
2005
$$$$
2004
$$$$
2005
$$ \\ 2008}

$$
\begin{aligned}
& 2005 \\
& 2006 \\
& 2006 \\
& 2008 \\
& 2009 \\
& 2009 \\
& 2005 \\
& 2005 \\
& 2005 \\
& 2005 \\
& 2005 \\
& 2007
\end{aligned}
$$

\section{Classical swine \\ Eurasian swine \\ Eurasian swine \\ Eurasian swine \\ Eurasian swine \\ Eurasian swine \\ Eurasian swine \\ Eurasian swine \\ Classical swine \\ Eurasian swine \\ Classical swine \\ Eurasian swine \\ Classical swine \\ Eurasian swine}

$\begin{array}{ll}\text { HM142750 } & \text { Eurasian swine } \\ \text { HM142751 } & \text { Eurasian swine } \\ \text { HM142752 } & \text { Eurasian swine } \\ \text { HM142753 } & \text { Eurasian swine } \\ \text { HM142754 } & \text { Eurasian swine } \\ \text { HM142755 } & \text { Eurasian swine } \\ \text { HM142746 } & \text { Classical swine } \\ \text { HM142747 } & \text { Classical swine } \\ \text { HM142748 } & \text { Classical swine } \\ \text { HM142749 } & \text { Classical swine } \\ \text { HM142756 } & \text { Eurasian swine } \\ \text { HM142757 } & \text { Eurasian swine }\end{array}$

acids at positions $31,33,61,100,109,136,214,377$, and 455 showed potentially human-specific characteristics even though such amino acids can be found in either avian or swine lineages (Table 3). Four amino acids unique to Eurasian and classical swine lineages were identified at positions $350(350 \mathrm{~K} / \mathrm{T}), 371(\mathrm{~V} / \mathrm{M}), 444(\mathrm{~V} /$ I), and $456(\mathrm{~L} / \mathrm{V})$. It should be noted that amino acids potentially unique to the pandemic H1N1 2009 were found at positions $100(100 \mathrm{I}), 217(217 \mathrm{~V}), 313(313 \mathrm{~V})$, $316(316 \mathrm{M})$ and $425(425 \mathrm{~V})$.

\section{Nucleotide substitution rate of the NP gene}

Nucleotide substitution rates of the NP gene in swine, human and avian lineage viruses were calculated using BEAST v1.4.7 applying the Bayesian Markov Chain Monte Carlo (BMCMC). In this study, the nucleotide substitution rates of the NP gene in both Eurasian and classical swine lineages viruses were high, amounting to $2.92 \times 10^{-3}$ and $2.98 \times 10^{-3}$, respectively. In addition, all human lineages (seasonal H1N1, H3N2 and pandemic H1N1) also displayed high nucleotide substitution rates of the NP gene (Table 4). On the other hand, the substitution rate of the NP gene in avian viruses was half $\left(1.57 \times 10^{-3}\right)$ that of swine and human lineages, indicating the highly conserved nature or genetically static stage of the NP gene of avian viruses compared to human and swine viruses.

\section{Discussion}

In this study, we determined the NP gene sequences of 12 Thai swine influenza virus subtypes $(\mathrm{H} 1 \mathrm{~N} 1$ and H3N2) recovered between 2005 and 2009. Previous 


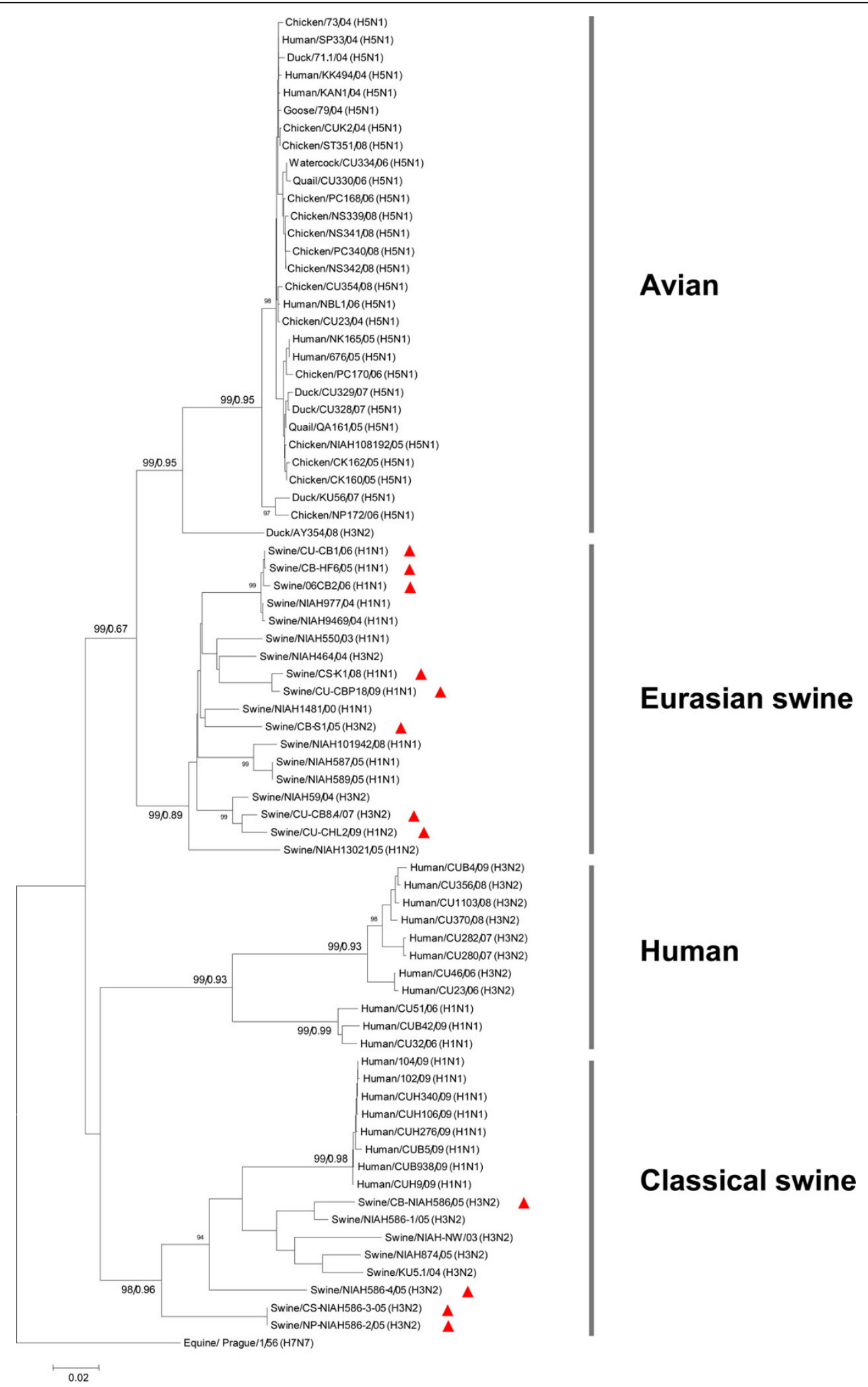

Figure 1 Phylogenetic tree of NP gene of influenza viruses recovered from swine, human and avian hosts in Thailand. The trees were generated using MEGA 4.0 applying the neighbor-joining algorithm. Tree topology was supported with bootstrap analysis with 1000 replicates and posterior probability from BMCMC analysis (Bootstrap, posterior probability). The swine influenza viruses characterized in the study are presented as triangles. 
Table 2 Pair-wise sequence comparison of complete NP gene nucleotide sequences of 12 swine viruses and those of reference viruses

\begin{tabular}{|c|c|c|c|c|c|c|c|}
\hline \multirow[t]{3}{*}{ Virus/year (subtype) } & \multirow[t]{3}{*}{ Host } & \multirow[t]{3}{*}{ Lineage } & \multicolumn{5}{|c|}{ Reference viruses } \\
\hline & & & Equine & Avian & Human & Eurasian swine & Classical Swine \\
\hline & & & $\mathrm{PR} / 56$ & CUK2 & CU32 & $9469 / 04$ & $\mathrm{~K} 5 / 04$ \\
\hline PR/56 (H7N7) & Equine & - & 100 & 83.7 & 81.9 & 83.8 & 82.4 \\
\hline CUK2/04 (H5N1) & Avian & Avian & 83.7 & 100 & 82.7 & 88.9 & 82.3 \\
\hline CU32/06 (sH1N1) & Human & Human & 81.9 & 82.7 & 100 & 82.6 & 84.1 \\
\hline 102/09 (pH1N1) & Human & Classical swine & 82.4 & 82.3 & 84.0 & 83.2 & 91.1 \\
\hline 9469/04 (H1N1) & Swine & Eurasian swine & 83.8 & 88.9 & 82.6 & 100 & 82.9 \\
\hline $\mathrm{HF6/05}(\mathrm{H} 1 \mathrm{~N} 1)^{*}$ & Swine & Eurasian swine & 83.8 & 88.8 & 82.7 & 99.7 & 83.0 \\
\hline 06CB2/06 (H1N1)* & Swine & Eurasian swine & 83.8 & 88.7 & 82.7 & 99.5 & 83.1 \\
\hline $\mathrm{CU}-\mathrm{CB} 1 / 06(\mathrm{H} 1 \mathrm{~N} 1)^{*}$ & Swine & Eurasian swine & 83.9 & 88.9 & 82.8 & 99.7 & 83.1 \\
\hline $\mathrm{CS}-\mathrm{K} 1 / 08(\mathrm{H} 1 \mathrm{~N} 1)^{*}$ & Swine & Eurasian swine & 84.2 & 88.2 & 82.5 & 93.5 & 82.5 \\
\hline CU-CBP18/09 (H1N1)* & Swine & Eurasian swine & 84.1 & 88.4 & 82.3 & 93.4 & 82.1 \\
\hline $\mathrm{CU}-\mathrm{CHL} 2 / 09(\mathrm{H} 1 \mathrm{~N} 2)^{*}$ & Swine & Eurasian swine & 83.2 & 88.8 & 82.3 & 94.4 & 83.0 \\
\hline $\mathrm{CU}-\mathrm{CB} 8.4 / 07(\mathrm{H} 3 \mathrm{~N} 2)^{*}$ & Swine & Eurasian swine & 83.6 & 89.2 & 82.6 & 94.3 & 82.9 \\
\hline CB-S1/05 (H3N2)* & Swine & Eurasian swine & 84.5 & 89.0 & 82.8 & 95.0 & 82.1 \\
\hline K5/04 (H3N2) & Swine & Classical swine & 82.4 & 82.3 & 84.1 & 82.9 & 100 \\
\hline CB-NIAH-586/05 (H3N2)* & Swine & Classical swine & 82.6 & 82.9 & 83.5 & 85.1 & 93.6 \\
\hline NP-NIAH-586-2/05 (H3N2)* & Swine & Classical swine & 82.7 & 85.1 & 82.5 & 87.1 & 91.2 \\
\hline CS-NIAH-586-3/05 (H3N2)* & Swine & Classical swine & 82.7 & 85.1 & 82.5 & 87.1 & 91.2 \\
\hline NIAH586-4/05 (H3N2)* & Swine & Classical swine & 82.5 & 83.4 & 82.7 & 85.7 & 90.5 \\
\hline
\end{tabular}

* The Thai swine viruses characterized in this study

Table 3 Analysis of unique amino acids for avian, human, classical swine and Eurasian swine lineages

\begin{tabular}{|c|c|c|c|c|c|c|c|c|c|c|c|c|c|c|c|c|c|c|}
\hline \multirow[t]{3}{*}{ Host } & \multirow[t]{3}{*}{ Lineage } & \multirow[t]{3}{*}{$\mathbf{n}$} & \multicolumn{16}{|c|}{ Deduced amino acid position of NP protein } \\
\hline & & & \multicolumn{14}{|c|}{ Human lineage } & \multicolumn{2}{|c|}{ Avian lineage } \\
\hline & & & 16 & 31 & 33 & 61 & 100 & 109 & 136 & 214 & 283 & 293 & 372 & 377 & 422 & 455 & 105 & 450 \\
\hline Equine & - & 1 & G & $\mathrm{K}$ & V & । & $\mathrm{R}$ & I & L & K & L & $\mathrm{R}$ & $\mathrm{E}$ & $\mathrm{N}$ & $\mathrm{R}$ & $\mathrm{D}$ & I & N 1 \\
\hline Avian & Avian & 25 & G & $\mathrm{R}$ & V & I & $\mathrm{R}$ & । & L & $\mathrm{R}$ & L & $\mathrm{R}$ & $E$ & $\begin{array}{l}\text { N24/ } \\
\text { S11 }\end{array}$ & $\mathrm{R}$ & D & V & S 24/G1 \\
\hline Human (H5N1) & Avian & 6 & G & $\mathrm{R}$ & V & 1 & $\mathrm{R}$ & 1 & L & $\mathrm{R}$ & $L$ & $\mathrm{R}$ & $\mathrm{E}$ & $\mathrm{N}$ & $\mathrm{R}$ & D & V & 56 \\
\hline $\begin{array}{l}\text { Human } \\
\text { (Seasonal) }\end{array}$ & Human & 11 & $\mathrm{D}$ & $\begin{array}{l}\text { K8/ } \\
\text { R3 }\end{array}$ & 1 & L & V & V & I & K & $P$ & K & $\mathrm{D}$ & $\mathrm{S} 9 / \mathrm{G} 2$ & K & $\begin{array}{l}\text { E10/ } \\
\text { D }\end{array}$ & $\begin{array}{l}\text { M8/ } \\
\text { V3 }\end{array}$ & S 5/G6 \\
\hline $\begin{array}{l}\text { Human } \\
\text { (Pandemic) }\end{array}$ & $\begin{array}{l}\text { Classical } \\
\text { swine }\end{array}$ & 8 & G & $\mathrm{R}$ & I & I & I & I & I & $\mathrm{R}$ & L & $\mathrm{R}$ & $E$ & $\mathrm{~N}$ & $\mathrm{R}$ & D & M & $S$ \\
\hline $\begin{array}{l}\text { Swine } \\
\text { (Eurasian) }\end{array}$ & $\begin{array}{l}\text { Eurasian } \\
\text { swine }\end{array}$ & 18 & G & $\mathrm{R}$ & V & $\begin{array}{l}\text { I15/ } \\
\text { M3 }\end{array}$ & $\mathrm{R}$ & $\begin{array}{l}116 / \\
\text { V2 }\end{array}$ & L & $\begin{array}{l}\text { R15/ } \\
\text { K3 }\end{array}$ & L & $\mathrm{R}$ & $E$ & V15/I3 & $\mathrm{R}$ & D & $\begin{array}{l}\mathrm{M} 17 / \mathrm{I} \\
1\end{array}$ & $\begin{array}{l}\text { S12/N5/ } \\
\text { G1 }\end{array}$ \\
\hline $\begin{array}{l}\text { Swine } \\
\text { (Classical) }\end{array}$ & $\begin{array}{l}\text { Classical } \\
\text { swine }\end{array}$ & 8 & G & $\mathrm{R}$ & $V 6 / 12$ & I & $\begin{array}{l}\text { V6/ } \\
\text { R2 }\end{array}$ & । & $\begin{array}{l}16 / \\
\mathrm{L} 2\end{array}$ & $\mathrm{~K} 7 / \mathrm{R}$ & L & $\mathrm{R}$ & $\mathrm{E}$ & N & $\mathrm{R}$ & D & M & $N 7 / R$ \\
\hline \multirow[t]{2}{*}{ Host } & Lineage & $\mathrm{n}$ & \multicolumn{16}{|c|}{ Swine lineage } \\
\hline & & & 217 & 289 & 313 & 316 & 350 & 357 & 371 & 373 & 384 & 400 & 425 & 433 & 444 & 456 & & \\
\hline Equine & - & 1 & I & $\mathrm{Y}$ & $\mathrm{F}$ & 1 & $\mathrm{~T}$ & Q & $M$ & $T$ & $\mathrm{R}$ & K & 1 & $\mathrm{~N}$ & 1 & V & & \\
\hline Avian & Avian & 25 & $\begin{array}{l}124 / \\
M\end{array}$ & Y & $\mathrm{F}$ & 1 & $\mathrm{~T}$ & Q & M & $\begin{array}{l}\text { A24/ } \\
\text { T1 }\end{array}$ & $\mathrm{R}$ & $\mathrm{R}$ & । & $\mathrm{T}$ & I & $\begin{array}{l}\text { V24/ } \\
\text { A1 }\end{array}$ & & \\
\hline Human (H5N1) & Avian & 6 & I & Y & $\mathrm{F}$ & I & $\mathrm{T}$ & $\mathrm{Q} 5 / \mathrm{K}$ & M & A & $\mathrm{R}$ & $\mathrm{R}$ & । & $\mathrm{T}$ & I & V & & \\
\hline $\begin{array}{l}\text { Human } \\
\text { (Seasonal) }\end{array}$ & Human & 11 & $\begin{array}{l}13 / \\
58\end{array}$ & Y & Y & । & $\mathrm{T}$ & K & M & $\begin{array}{l}\mathrm{N} 8 / \\
\mathrm{A} 3\end{array}$ & $\mathrm{R}$ & R & । & $\mathrm{T}$ & I & V & & \\
\hline $\begin{array}{l}\text { Human } \\
\text { (Pandemic) }\end{array}$ & $\begin{array}{l}\text { Classical } \\
\text { swine }\end{array}$ & 8 & V & $\mathrm{H}$ & V & M & K & K & V & $\mathrm{T}$ & $\begin{array}{l}\text { G8/ } \\
\text { R3 }\end{array}$ & K & V & N & V & L & & \\
\hline $\begin{array}{l}\text { Swine } \\
\text { (Eurasian) }\end{array}$ & $\begin{array}{l}\text { Eurasian } \\
\text { swine }\end{array}$ & 18 & । & Y & $\begin{array}{l}\mathrm{F} 16 / \\
\mathrm{L} 2\end{array}$ & I & $\mathrm{T}$ & $\begin{array}{l}\text { Q17/ } \\
\text { K1 }\end{array}$ & M & $\mathrm{T}$ & K & $\begin{array}{l}\mathrm{R} 17 / \\
\mathrm{K} 1\end{array}$ & । & $\begin{array}{l}\text { T17/ } \\
\text { N1 }\end{array}$ & । & V & & \\
\hline $\begin{array}{l}\text { Swine } \\
\text { (Classical) }\end{array}$ & $\begin{array}{l}\text { Classical } \\
\text { swine }\end{array}$ & 8 & $17 / N$ & $\begin{array}{l}\mathrm{H} 6 / \\
\text { Y2 }\end{array}$ & $\mathrm{F}$ & I & K & K & V & A & $\mathrm{R}$ & K & $17 N$ & $\mathrm{~N}$ & V & $L$ & & \\
\hline
\end{tabular}


Table 4 Nucleotide substitution rates of NP gene of swine, human and avian influenza viruses in Thailand

\begin{tabular}{cccc}
\hline & $\mathbf{n}$ & Mean Substitution Rate $\left(\times \mathbf{1 \mathbf { 0 } ^ { - 3 }}\right)$ & Substitution Rate HPD $\left(\times \mathbf{1 0 ^ { - 3 }}\right)$ \\
\hline Avian H5N1 & 91 & 1.57 & $0.92-2.22$ \\
Eurasian Swine & 18 & 2.92 & $1.87-3.97$ \\
Classic Swine & 8 & 2.98 & $1.56-4.30$ \\
Human Seasonal H1N1 & 14 & 2.11 & $1.32-2.88$ \\
Human Seasonal H3N2 & 22 & 2.56 & $0.69-4.40$ \\
Human Pandemic H1N1 & 8 & 2.57 & $1.79-3.21$ \\
\hline
\end{tabular}

reports have provided some NP gene sequences of swine influenza viruses from Thailand $[17,18]$. However, none of those NP gene sequences has been comprehensively characterized. Since only 14 NP nucleotide sequences of Thai swine viruses have been stored at the public database, the results obtained from this study could help add significant information on swine influenza viruses in Thailand.

Phylogenetic analysis of the NP gene of 76 selected influenza viruses from Thailand and one representative for the NP gene (A/Equine/Prague/1/56 (H7N7) confirmed distinct clusters of the NP gene as equine, avian, human, European swine and classical swine lineages (Fig $1)$. The NP gene of influenza viruses has been distinguished into human and non-human groups [6-8]. Host specific NP groups including equine 1, recent equine, human-classical swine, H13 gull and avian differentiated by both RNA hybridization and phylogenetic analysis have been reported in previous studies [3,5]. Avian-like swine (Eurasian swine) and classical swine lineages have also been documented [19]. The result of this study confirmed that the NP gene is highly conserved within host-specific lineages. Most avian, human and swine viruses in Thailand cluster within their specific host ranges. For example, all avian influenza viruses as well as human $\mathrm{H} 5 \mathrm{~N} 1$ viruses cluster in the avian lineage, while seasonal human $\mathrm{H} 1 \mathrm{~N} 1$ and $\mathrm{H} 3 \mathrm{~N} 2$ are grouped with a separate human lineage. It should be noted that avian $\mathrm{H} 5 \mathrm{~N} 1$ viruses have been isolated from several mammalian species such as humans, tigers, cats, dogs and possibly other domestic animals. However these $\mathrm{H} 5 \mathrm{~N} 1$ viruses displayed avian characteristics and were grouped with the avian linage [20-22]. In addition, several studies have reported that the NP gene of pandemic H1N1 2009 displays classical swine characteristics $[14,15]$. Evidence of the pandemic H1N1 2009 human viruses displaying a swine-like NP gene and of $\mathrm{H} 5 \mathrm{~N} 1$ human viruses containing an avian NP gene has suggested that the NP gene can be utilized for tracing interspecies transmission of animal Influenza A viruses to humans. Further research conducted on the NP gene from various animal species and humans with respect to its host specificity could be useful for monitoring influenza A viruses.
None of the unique amino acids of NP lineages identified in this study is involved in RNA binding activities [10]. They are mainly correlated with host specificity of the viruses. Genetic analysis of the NP gene of the 12 swine influenza viruses has shown that the viruses display high nucleotide sequence identities similar to either Eurasian swine or classical swine viruses. Four potentially unique amino acids specific to Eurasian and classical swine lineages but not avian or human lineages have been identified at positions $350(\mathrm{~K} / \mathrm{T}), 371$ (V/M), 444 $(\mathrm{V} / \mathrm{I})$, and $456(\mathrm{~L} / \mathrm{V})$. In contrast, amino acids at positions 345 and 430 have been reported as amino acids unique to the classical swine lineage [23]. Two amino acids at positions 105 and 450 have been reported as amino acids specific for avian lineages [19]. However the research presented here has not established the amino acid at position $405(405 \mathrm{~V})$ as highly correlated with the avian specific lineage as previously reported (Table 3) [3]. This study has also analyzed at least 5 amino acid positions $(16,283,293,372$, and 422) unique to the human lineage indicating that $283 \mathrm{P} / 283 \mathrm{~L}$ are specific to human and avian lineages, respectively, as previously reported [24-26]. It has been known that the amino acid at position 16 is related to the $\mathrm{N}$-terminal cleavage of the NP gene and correlated with the host specificity of the virus [27]. The amino acid motif of the NP gene of the human virus (ETD16G) is sensitive to host protease, while that of avian and swine viruses (ETG16G) is resistant [28,29]. Moreover, in this study, we were able to identify at least 5 amino acids of the NP gene $(100,217,313,316$, and 425$)$ unique to the pandemic H1N1 2009 viruses. Previous studies analyzed the NP gene of H1N1 2009 stored at the public database and the result showed that the amino acids V100 and V313 were highly conserved in the pandemic H1N1 2009 virus [30]. In addition, the tendency of a V to I mutation in NP100 has also been previously reported, similar to the finding in this study [26].

\section{Conclusion}

In conclusion, our study provided the nucleotide sequences of the NP gene of 12 Thai swine influenza viruses of subtypes H1N1, H1N2 and H3N2. Phylogenetic and genetic analysis of the swine, avian and 
human influenza viruses confirmed the highly conserved nature of the NP gene within host-specific lineages. The NP gene of swine influenza viruses clustered with either Eurasian swine or classical swine viruses indicating the origins of the imported viruses. Unique amino acids specific to swine, avian and human influenza lineages were identified. This research highlights the significance of genetic variation of the NP gene from swine, avian and human influenza viruses in Thailand.

\section{Materials and methods}

\section{Influenza A Virus from swine}

The 12 swine influenza viruses in this study were isolated from swine raised in Thailand between 2005 and 2009. The viruses were obtained from swine farms in provinces of the central region (Saraburi, Ratchaburi and Nakhon Pathom) and eastern region (Chonburi and Chachoengsao) of Thailand. Virus isolation was performed as previously described [18]. The viruses were confirmed as influenza A virus by one-step realtime RT-PCR with primers and probe specific to the $M$ gene. The viruses were then subtyped as H1N1 $(\mathrm{n}=6), \mathrm{H} 1 \mathrm{~N} 2(\mathrm{n}=1)$ and H3N2 $(n=5)$ by using primers specific to each subtype of swine influenza viruses (list of primers is available upon request). The viruses were propagated in Madin-Darby canine kidney (MDCK) cells in minimal essential medium (MEM) (Hyclone, USA) with 5\% fetal calf serum (Hyclone) for 3 passages for further NP gene sequencing.

\section{Complete NP gene sequencing}

Viral RNA was extracted from cell culture by using a QIAmp viral RNA mini kit (Qiagen, Hilden, Germany). cDNA synthesis of viral RNA and amplification of the NP gene by PCR were performed with specific primers with some modifications (Hoffman et al., 2001). In brief, cDNA synthesis was carried out by incubating the viral RNA with $0.5 \mathrm{ug}$ of random primers at $70^{\circ} \mathrm{C}$ for $5 \mathrm{~min}$ and $4^{\circ} \mathrm{C}$ for $5 \mathrm{~min}$. The mixture was added to $1 \times$ reaction buffer (Promega, Madison WI), $0.5 \mathrm{mM}$ dNTPs, $2.5 \mathrm{mM}$ $\mathrm{MgCl} 2,10 \mathrm{U}$ of RNAsin Ribonuclease inhibitor and $1 \mathrm{U}$ of ImProm-II Reverse Transcriptase and incubated at $25^{\circ}$ $\mathrm{C}$ for $5 \mathrm{~min}, 42^{\circ} \mathrm{C}$ for $60 \mathrm{~min}$ and $70^{\circ} \mathrm{C}$ for $15 \mathrm{~min}$. Amplification of the NP gene was carried out in $50 \mathrm{ul}$ of PCR mixture by adding $4 \mathrm{ul}$ of cDNA, $1 \times$ master mix (ReadyMix PCR master mix, Thermo Fisher Scientific, UK) and 0.5 umol of oligonucleotide primers specific to the NP gene. The amplification reaction included an initial denaturation step at $94^{\circ} \mathrm{C}$ for $3 \mathrm{~min}$, followed by 40 cycles of denaturation at $94^{\circ} \mathrm{C}$ for $30 \mathrm{~s}$, annealing at $55^{\circ} \mathrm{C}$ for $30 \mathrm{~s}$ and extension at $72^{\circ} \mathrm{C}$ for $30 \mathrm{~s}$, and concluded by a final extension step at $72^{\circ} \mathrm{C}$ for $7 \mathrm{~min}$. The PCR products were mixed with loading buffer $(2 \%$ Orange G in $50 \%$ glycerol) and then separated by $1.5 \%$ agarose gel electrophoresis (FMC Bioproducts, Rockland,
ME). PCR products of interest were purified by the QIAquick Gel Extraction Kit (Qiagen). DNA sequencing was carried out by dideoxynucleotide chain termination technique. Briefly, the sequencing reaction was performed using Big Dye Terminator V3.0 Cycle Sequencing Ready reaction (ABI, Foster city, $\mathrm{CA}$ ) at a final volume of $20 \mathrm{ul}$ containing $1 \times$ reaction dye terminator and $3.2 \mathrm{pmol}$ of specific sequencing primers. The product of the sequencing reaction was analyzed in the ABI-Prism 310 Genetic Analyzer (Perkin Elmer, Norwalk, CT).

\section{Analysis of genetic variation of the NP gene of Swine influenza viruses}

Nucleotide sequences were edited, validated and assembled by using Chromas version 1.45 (Technelysium Pty. Ltd., Australia), and SeqMan (DNASTAR, Madison, WI). The complete nucleotide sequences of the NP gene of influenza viruses from swine were submitted to the GenBank database with accession numbers shown in Table 1. Phylogenetic analyses were conducted in MEGA version 4 [31] using neighbor-joining method with Kimura 2-parameter. Bootstrap analysis was performed with 1000 replicates. The Bayesian tree was generated using the MrBayes V.3.1.2 [32] with 1 million generations using default heating parameters. The posterior probabilities were calculated to confirm tree topology. Genetic analyses for amino acid polymorphisms of the NP gene from viruses isolated from different host species were performed by amino acid alignments using the MegAlign program (DNASTAR). Additional NP nucleotide sequences from Thai seasonal H1N1 $(\mathrm{n}=3)$, H3N2 $(\mathrm{n}=8)$ and pandemic (H1N1) $2009(\mathrm{n}=8)$ from humans as well as those from Thai HPAI $(\mathrm{H} 5 \mathrm{~N} 1)$ from avian species $(\mathrm{n}=24)$ and humans $(\mathrm{n}=6)$ were included for phylogenetic and genetic analyses.

\section{Nucleotide substitution rates of the NP gene}

Nucleotide substitution rates of the NP gene of swine, human and avian influenza A viruses recovered from 2003-2009 in Thailand were calculated using the computer program BEAST v1.4.7 applying the Bayesian Markov Chain Monte Carlo (BMCMC) [33]. Each nucleotide sequence was analyzed by codon-positionspecific $\mathrm{HKY}+\Gamma$ substitution model as well as clock models (strict clock, uncorrelated relaxed clock and correlated relaxed clock). The BMCMC analysis was conducted with the parameters of at least 50 million states with 1000 sampling intervals and the $10 \%$ of each chain are 'burn-in' removed. The BMCMC analysis results were shown using Tracer V1.4.

\section{Acknowledgements}

This study was supported by the Thailand Research Fund (TRF Master Research Grants: MAG-WII515S055) to Dr. Amonsin, the $90^{\text {th }}$ Anniversary of 
Chulalongkorn University Fund (Ratchadaphiseksomphot Endowment Fund) to NT. We also would like to thank the National Research Council of Thailand for the research grant to PK. This study was funded in part by Emerging Health Risk Cluster, the Ratchadaphiseksomphot Endowment Fund. We would like to thank Ms. Petra Hirsch for reviewing the manuscript.

\section{Author details}

${ }^{1}$ Emerging and Re-emerging Infectious Diseases in Animals, Research Unit, Faculty of Veterinary Science, Chulalongkorn University, Bangkok, 10330 Thailand. ${ }^{2}$ Center of Excellence in Clinical Virology, Faculty of Medicine, Chulalongkorn University, Bangkok, 10330, Thailand. ${ }^{3}$ National Institute of Animal Health, Department of Livestock Development, Bangkok, Thailand.

\section{Authors' contributions}

NT performed genome sequencing of the NP gene, phylogenetic analysis and drafted the manuscript. PK, RT SP and SD participated in virus isolation and drafting of the manuscript. DS conducted virus isolation. AT, YP and KS performed genetic and phylogenetic analyses. AA was responsible for experimental design, analyses and final approval of the manuscript. All authors read and approved the final manuscript.

\section{Competing interests}

The authors declare that they have no competing interests.

Received: 19 June 2010 Accepted: 9 August 2010

Published: 9 August 2010

\section{References}

1. De Jong JC, Rimmelzwaan GF, Fouchier RA, Osterhaus AD: Influenza virus: a master of metamorphosis. J Infect 2000, 40:218-228.

2. Nicholson KG, Wood JM, Zambon M: Influenza. Lancet 2003, 362:1733-1745.

3. Gorman OT, Bean WJ, Kawaoka Y, Webster RG: Evolution of the nucleoprotein gene of influenza A virus. J Virol 1990, 64:1487-1497.

4. Scholtissek C, Burger $\mathrm{H}$, Kistner O, Shortridge KF: The nucleoprotein as a possible major factor in determining host specificity of influenza H3N2 viruses. Virology 1985, 147:287-294.

5. Bean WJ: Correlation of influenza A virus nucleoprotein genes with host species. Virology 1984, 133:438-442.

6. Reid AH, Fanning TG, Janczewski TA, Lourens RM, Taubenberger JK: Novel origin of the 1918 pandemic influenza virus nucleoprotein gene. J Virol 2004, 78:12462-12470.

7. Buckler-White AJ, Murphy BR: Nucleotide sequence analysis of the nucleoprotein gene of an avian and a human influenza virus strain identifies two classes of nucleoproteins. Virology 1986, 155:345-355.

8. Gammelin M, Mandler J, Scholtissek C: Two subtypes of nucleoproteins (NP) of influenza A viruses. Virology 1989, 170:71-80

9. Portela A, Digard P: The influenza virus nucleoprotein: a multifunctional RNA-binding protein pivotal to virus replication. J Gen Virol 2002, 83:723-734.

10. Wang P, Palese P, O'Neill RE: The NPI-1/NPI-3 (karyopherin alpha) binding site on the influenza a virus nucleoprotein NP is a nonconventional nuclear localization signal. J Virol 1997, 71:1850-1856.

11. Newcomb LL, Kuo RL, Ye Q, Jiang Y, Tao YJ, Krug RM: Interaction of the influenza a virus nucleocapsid protein with the viral RNA polymerase potentiates unprimed viral RNA replication. J Virol 2009, 83:29-36.

12. Yewdell JW, Bennink JR, Smith GL, Moss B: Influenza A virus nucleoprotein is a major target antigen for cross-reactive anti-influenza $A$ virus cytotoxic T lymphocytes. Proc Natl Acad Sci USA 1985, 82:1785-1789.

13. Elton $D$, Medcalf $L$, Bishop $K$, Harrison D, Digard P: Identification of amino acid residues of influenza virus nucleoprotein essential for RNA binding. J Virol 1999, 73:7357-7367.

14. Garten RJ, Davis CT, Russell CA, Shu B, Lindstrom S, Balish A, Sessions WM, Xu X, Skepner E, Deyde V, et al: Antigenic and genetic characteristics of swine-origin $2009 \mathrm{~A}(\mathrm{H} 1 \mathrm{~N} 1)$ influenza viruses circulating in humans. Science 2009, 325:197-201.

15. Kingsford C, Nagarajan N, Salzberg SL: 2009 Swine-origin influenza A (H1N1) resembles previous influenza isolates. PLoS One 2009, 4:e6402.

16. Dunham EJ, Dugan VG, Kaser EK, Perkins SE, Brown IH, Holmes EC, Taubenberger JK: Different evolutionary trajectories of European avianlike and classical swine H1N1 influenza A viruses. J Virol 2009, 83:5485-5494.
17. Chutinimitkul S, Thippamom N, Damrongwatanapokin S, Payungporn S, Thanawongnuwech R, Amonsin A, Boonsuk P, Sreta D, Bunpong N, Tantilertcharoen R, et al: Genetic characterization of H1N1, H1N2 and H3N2 swine influenza virus in Thailand. Arch Virol 2008, 153:1049-1056.

18. Sreta D, Kedkovid R, Tuamsang S, Kitikoon P, Thanawongnuwech R: Pathogenesis of swine influenza virus (Thai isolates) in weanling pigs: an experimental trial. Virol J 2009, 6:34.

19. Gorman OT, Bean WJ, Kawaoka Y, Donatelli I, Guo YJ, Webster RG: Evolution of influenza A virus nucleoprotein genes: implications for the origins of H1N1 human and classical swine viruses. J Virol 1991, 65:3704-3714.

20. Songsermn T, Amonsin A, Jam-on R, Sae-Heng N, Meemak N, Pariyothorn N, Payungporn S, Theamboonlers A, Poovorawan Y: Avian influenza H5N1 in naturally infected domestic cat. Emerg Infect Dis 2006, 12:681-683.

21. Songserm T, Jam-on R, Sae-Heng N, Meemak N, Hulse-Post DJ, SturmRamirez KM, Webster RG: Domestic ducks and H5N1 influenza epidemic, Thailand. Emerg Infect Dis 2006, 12:575-581.

22. Amonsin A, Payungporn S, Theamboonlers A, Thanawongnuwech R, Suradhat S, Pariyothorn N, Tantilertcharoen R, Damrongwantanapokin S, Buranathai $C$, Chaisingh A, et al: Genetic characterization of H5N1 influenza A viruses isolated from zoo tigers in Thailand. Virology 2006, 344:480-491.

23. Arora DJ: Drift in the nucleoprotein gene of swine influenza virus (H1N1) causing respiratory disease in pigs. Virus Genes 2002, 25:109-111.

24. Kim JH, Hatta M, Watanabe S, Neumann G, Watanabe T, Kawaoka Y: Role of host-specific amino acids in the pathogenicity of avian $\mathrm{H} 5 \mathrm{~N} 1$ influenza viruses in mice. J Gen Virol 2009, 91:1284-1289.

25. Chen GW, Chang SC, Mok CK, Lo YL, Kung YN, Huang JH, Shih YH, Wang JY, Chiang C, Chen CJ, Shih SR: Genomic signatures of human versus avian influenza A viruses. Emerg Infect Dis 2006, 12:1353-1360.

26. Pan C, Cheung B, Tan S, Li C, Li L, Liu S, Jiang S: Genomic signature and mutation trend analysis of pandemic (H1N1) 2009 influenza A virus. PLoS One 2009, 5:e9549.

27. Zhirnov OP: The host origin of influenza $A$ viruses can be assessed by the intracellular cleavage of the viral nucleocapsid protein. Brief report. Arch Virol 1988, 99:277-284.

28. Zhirnov OP, Konakova TE, Garten W, Klenk H: Caspase-dependent Nterminal cleavage of influenza virus nucleocapsid protein in infected cells. J Virol 1999, 73:10158-10163.

29. Zhirnov OP, Syrtzev W: Influenza virus pathogenicity is determined by caspase cleavage motifs located in the viral proteins. $J$ Mol Genet Med 2009, 3:124-132.

30. Chen GW, Shih SR: Genomic signatures of influenza A pandemic (H1N1) 2009 virus. Emerg Infect Dis 2009, 15:1897-1903.

31. Kumar S, Nei M, Dudley J, Tamura K: MEGA: a biologist-centric software for evolutionary analysis of DNA and protein sequences. Brief Bioinform 2008, 9:299-306.

32. Huelsenbeck JP, Ronquist F: MRBAYES: Bayesian inference of phylogenetic trees. Bioinformatics 2001, 17:754-755.

33. Drummond AJ, Rambaut A: BEAST: Bayesian evolutionary analysis by sampling trees. BMC Evol Biol 2007, 7:214.

\section{doi:10.1186/1743-422X-7-185}

Cite this article as: Thippamom et al:: Genetic variations of nucleoprotein gene of influenza A viruses isolated from swine in Thailand. Virology Journal 2010 7:185. 